\title{
The effects of cardiac rehabilitation on overall physical capacity and myocardial perfusion in women with microvascular angina
}

\author{
Wojciech Szot ${ }^{1,2}$, Joanna Zając ${ }^{1}$, Aleksandra Kubinyi ${ }^{3}$, Magdalena Kostkiewicz ${ }^{2,4}$ \\ ${ }^{1}$ Hygiene and Dietetics Department, Jagiellonian University Medical College, Krakow, Poland \\ ${ }^{2}$ Nuclear Medicine Department, John Paul II Hospital, Krakow, Poland \\ ${ }^{3}$ Belluga-Med Rehabilitation Centre, Krakow, Poland \\ ${ }^{4}$ Department of Cardiac and Vascular Diseases, Jagiellonian University Medical College, Krakow, Poland
}

\begin{abstract}
Background: Cardiac syndrome X (CSX) is linked with changes in microcirculation, without significant changes in main coronary vessels. According to European Society of Cardiology 2013 stable coronary artery disease (CAD) criteria, CSX was replaced by microvascular angina (MA). The main feature of MA should be regional myocardial ischaemia; however, there are several works on this subject which failed to demonstrate the presence of perfusion defects.

Aim: To determine the effect of non-pharmacological procedures (cardiac rehabilitation) in patients diagnosed with MA on changes in left ventricular perfusion as assessed by myocardial single photon emission computed tomography, along with potential related improvements in exercise capacity.

Methods: Toward this goal we screened for the presence of CAD in a group of 528 women, of whom 55 were not only diagnosed with MA but also agreed to participate in our study, which involved myocardial perfusion imaging (MPI) studies, during which exercise tests and cardiac rehabilitation were performed.

Results: Comparison of results obtained at the beginning of the study with data obtained after completion of a three month period of cardiac rehabilitation showed improvements in both exercise test parameters (length of test, metabolic equivalents, blood pressure control during extortion) and MPI parameters for the left ventricle (both at rest and stress, global and regional).
\end{abstract}

Conclusions: Cardiac rehabilitation is a very useful tool of choice in the treatment of patients with MA.

Key words: cardiac rehabilitation, myocardial perfusion imaging, microvascular angina

Kardiol Pol 2016; 74, 5: 431-438

\section{INTRODUCTION}

Cardiac syndrome $X$ (CSX), more widely known as microvascular angina (MA), was counted among stable coronary syndromes. The term 'cardiac syndrome $X$ ' was first used in 1973 by Kemp [1] to refer to patients with normal vascular arteriograms and impaired systolic function of the left ventricle (LV). However, CSX was not linked to changes in coronary microcirculation until 1988, when Cannon and Epstein [2] reported a link between the occurrence of chest pain and electrocardiogram (ECG) changes with changes in micro- circulation. Nevertheless, there is still some discussion as to whether CSX should be treated as a form of ischaemic heart disease (IHD). In a number of studies, the authors were unable to demonstrate ischaemia despite the fulfilment of other diagnostic criteria for CSX [2-4]. Some authors report that patients with CSX account for about $10-20 \%$ of all patients with symptoms of angina pectoris, a large percentage (> 70\%) of whom are women in peri- or postmenopausal phases [4]. In more than $50 \%$ of patients with CSX, there is a characteristic persistence of chest pain more than 10-20 min after the end 
of exercise, and poor or no response to short-acting nitrates $[5,6]$. Nonetheless, the term "cardiac syndrome X" no longer exists in guidelines, having been replaced by "microvascular angina" [7] identified with small vessel disease. In the case of the original form of MA, corresponding to the primary form of CSX, patients form a very diverse group, often with numerous, clearly severe risk factors for coronary artery disease (CAD), but just as often with virtually none. The conclusion is that MA actually encompasses several pathogenic mechanisms and conditions. Of importance, dysfunction of coronary microvasculature may occur along with other cardiac diseases, including changes in main coronary vessels [7].

A major problem is that patients with $M A$, excluding those with the classic form of the disease involving ischaemic main coronary vessels, often fail to receive proper medical treatment. The underlying cause is probably due to the poorly-understood background of the disease, along with the heterogeneity of the patient base, arising from the complexity of the symptoms and other underlying circumstances (e.g. changes in pain perception in post-menopausal women, hormonal changes). Currently, there are no explicit guidelines for the therapeutic treatment of MA. Empirical methods can be divided into pharmacological and non-pharmacological. Pharmacological treatment is based primarily on the standard medications used for IHD [8]. Non-pharmacological interventions consist primarily of lifestyle changes, diet modification, and increased physical activity.

The aim of this study was to determine the effect of non-pharmacological procedures (cardiac rehabilitation) in patients diagnosed with MA on changes in LV perfusion as assessed by myocardial single photon emission computed tomography (SPECT), along with potential related improvements in exercise capacity.

\section{METHODS}

\section{Screening}

In the period May 2008-December 2012, a group of 528 women considered to be in intermediate risk group underwent screening for the presence of IHD in the Nuclear Medicine Department, John Paul II Specialist Hospital in Krakow. All women underwent routine myocardial perfusion imaging (MPI) SPECT study, as recommended by European Society of Cardiology (ESC) guidelines regarding patients with intermediate risk for CAD. According to ESC criteria [7], MA can be taken into consideration in patients who experience typical angina symptoms, while no changes in coronary vessels are present, with the proof of ischaemia in ECG/MPI. Thus, the presence of perfusion defects in MPI SPECT without vascular changes in main coronary vessels in coronary angiography or angio-computed tomography (CT) constituted the inclusion criteria in our study group.

Out of the studied 528 women, MPI SPECT study confirmed the presence of various perfusion disorders in
436 women. Within this group of patients, in 158 individuals coronary angiography or angio-CT scan did not confirm the presence of vascular changes in the main coronary vessels, thus making subjects possible to be recognised as having MA. From those, a total group of 55 patients agreed to further participation in the study and cardiac rehabilitation.

\section{Basic anthropometric survey}

Basic anthropometric survey included:

- body weight measurement (rounded to the nearest $100 \mathrm{~g}$ );

- body height measurement (accurate within $1 \mathrm{~cm}$, in accordance with the principles of anthropometric testing). On the basis of measurements of body weight and height, body mass index $\left(\mathrm{BMI}=\right.$ body weight $[\mathrm{kg}] /$ height body $[\mathrm{m}]^{2}$ ) was calculated according to World Heart Organisation criteria.

\section{Stress test on a treadmill}

Tests were performed on a treadmill according to the modified Bruce protocol. The test consists of brisk walking in consecutive 3-min stages, with each succeeding stage done using an increased angle of inclination and difficulty expressed in units of metabolic equivalents [METs]. While increasing the difficulty, the physical exercise was adapted to the current EANM/ESC guidelines for conducting and evaluating the test [9].

\section{Myocardial perfusion scintigraphy - study protocol}

Studies using radioisotopes were performed according to a two-day protocol $[9,10]$.

- the first day a stress test was performed, which included exercise on a treadmill, for all patients; a radioisotope tracer was administered at peak stress;

- on the second day the tests were performed at rest.

In both the stress and resting tests, data acquisition was carried out in the 40-60 min following tracer injection using a dual-head gamma-camera (E.CAM by Siemens Medical Systems, Inc.) with a $64 \times 64$ matrix. Radionuclide scintigraphy was performed using the gated method (GSPECT) with a preparation of technetium-99 combined with MIBI administered intravenously with an activity of $18-25 \mathrm{mCi}$ (700-925 MBq). Corridor 4DM reconstruction software supplied by Siemens was used to process the acquired raw data.

As the data were acquired, image reconstruction was performed, enabling images of the three sections of the LV to be obtained, i.e. along the horizontal long axis, vertical long axis, and short axis. Cross-section cardiac images, divided into 17 segments, were evaluated using the semi-quantitative method.

For the purposes of this study the extent of the tracer uptake in the individual segments was assessed on the Visual Score five-point scale, where the degree of tracer accumulation corresponded to the following points:

- 0 - standard image of the heart muscle (normal perfusion); 
- 1 - slight impairment of tracer accumulation or non-uniformly marked heart muscle $(50-70 \%$ preserved perfusion) (equivocal);

- 2 - significantly reduced non-uniform uptake of Tc-99m-MIBI (30-50\% preserved perfusion) (mild perfusion change);

- 3- heart area only 'marked' (10-30\% preserved perfusion) (severe perfusion deficit);

- 4 - 'cold' scintigraphy image - complete absence of accumulation of Tc-99m-MIBI (0-10\% preserved perfusion) (no tracer uptake).

\section{Cardiac rehabilitation}

Activities in the field of rehabilitation were conducted at the Beluga Med, Healthcare Centre, three times a week for three months. We adopted the rehabilitation program from the American guidelines to manage cardiovascular prevention and rehabilitation that were available in the year 2008 when we started our study [11]. Prior to beginning the cycle, the maximum allowable difficulty level was calculated for each individual patient based on age, using the results of the final stress test done during scintigraphy.

Activities were completed for 90 min in groups of six, and consisted of:

- warm-up - $30 \mathrm{~min}$. During the warm-up the patients exercised all muscle groups, coordinated with inhalation and exhalation. The training cycles included both dynamic and static exercises. Exercises impeding breathing and causing apnoea were eliminated. As the training proceeded, patients were exposed to increasing difficulty and increased their pace and number of exercises during the warm-up;

- training using a bicycle ergometer with gradually increasing difficulty, selected individually - 30 min. During this phase heart rate, ECG, and blood pressure were continuously monitored. The entire three-month training cycle was divided into three parts, each lasting approximately four weeks, in which continually increasing maximum workloads were attempted: in the first stage $70 \mathrm{~W}$, the second $100 \mathrm{~W}$, and the third $120 \mathrm{~W}$. If at any point in this part of the training the heart rate limit $(80 \%$ heart rate) was exceeded, or the patients experienced symptoms of shortness of breath with modified Borg scale value score exceeding 4 , the ergometer load was reduced accordingly;

- relaxation exercises.

Trained in successive phases, the group was subjected to increasing difficulty, both during the warm-up (by gradually increasing the number of repetitions and the degree of difficulty of the exercise) as well as during exercise using a bicycle ergometer.

Training using a bicycle ergometer was conducted on Aspel equipment.

\section{Statistical analysis}

The statistical analysis of the data obtained in our study was performed using STATISTICA 10.0 ${ }^{\text {TM }}$ Software. The comparison of parameters obtained at baseline and after completion of cardiac rehabilitation was performed using the student t-test for repeated measures.

\section{RESULTS}

We studied 55 patients, aged 49-69 years. The mean age was $57.25 \pm 5.43$ years. Heights of patients ranged from 1.54 to $1.71 \mathrm{~m}$ (mean $1.63 \pm 0.05$ ). The mean BMI was $27.53 \pm 2.87$ and values ranged from 21.94 to 34.6 . In the studied group the following comorbidities were present: hypertension in 31 (56.4\%) women - all of them undergoing treatment; hyperlipidaemia in 29 (52.7\%) women, 26 undergoing pharmacologic treatment and life-style changes, the remaining three patients had only life-style changes; six women were smokers; two patients were suffering from mild renal disorders; and no patients suffered from diabetes.

Data obtained from scintigraphy at baseline in studied group showed, on average, in areas corresponding to the three major coronary arteries, significantly higher uptake values at rest studies than in stress ones, which indicates the presence of reversible perfusion defects.

Comparing summed difference scores between stress and rest studies in areas complementary to main coronary vessels, it was noted that:

- for segments corresponding to the area of left anterior descending artery (LAD) region, a mean value of $1.4 \pm$ \pm 1.49 was obtained, which should be interpreted as a slight inclination toward reversible perfusion defects prevalence over permanent changes;

- for segments corresponding to the area of the circumflex artery $(\mathrm{Cx})$ region, a mean value of $0.36 \pm 0.75$ was obtained;

- for segments corresponding to the area of the right coronary artery $(\mathrm{RCA})$ region, a mean value of $1.33 \pm 1.36$ was obtained, which should be interpreted as a slight inclination toward reversible perfusion defects prevalence.

The obtained overall summed difference score value for LV perfusion in the study group was $3.09 \pm 1.58$. Considering the absence of significant changes in the coronary arteries verified in all patients by angiography or CT, it was assumed that the presence of reversible perfusion defects was most likely attributable to the presence of MA.

In all patients, a stress test on a treadmill according to the modified Bruce protocol was conducted at baseline. In the case of systolic blood pressure (SBP) prior to the stress test, $49(89.09 \%)$ patients were within the normal range, while for six (10.81\%) patients SBP was within the range 145-160 mm $\mathrm{Hg}$. In the case of diastolic blood pressure (DBP) prior to the stress test, 51 (92.73\%) patients were within the normal range; the remaining four (7.27\%) were in the range 91-100 $\mathrm{mm} \mathrm{Hg}$. 
Table 1. Comparison of body weight, body mass index, and parameters obtained during exercise treadmill study at baseline and after completion of cardiac rehabilitation course

\begin{tabular}{|lccc|} 
& Baseline & After rehabilitation & P* \\
\hline Weight $[\mathrm{kg}]$ & $72.8 \pm 8.2$ & $71.23 \pm 6.81$ & $<0.001$ \\
Body mass index $\left[\mathrm{kg} / \mathrm{m}^{2}\right]$ & $27.53 \pm 2.87$ & $27.0 \pm 2.52$ & $<0.001$ \\
Systolic blood pressure value at baseline $[\mathrm{mm} \mathrm{Hg}]$ & $134.91 \pm 11.03$ & $128.55 \pm 8.64$ & $<0.001$ \\
Diastolic blood pressure value at baseline $[\mathrm{mm} \mathrm{Hg}]$ & $81.55 \pm 8.38$ & $77.82 \pm 7.86$ & $<0.001$ \\
Heart rate value at baseline & $83.15 \pm 10.81$ & $78.07 \pm 7.39$ & $<0.001$ \\
Length of exercise test $[\mathrm{s}]$ & $635.87 \pm 157.07$ & $760.02 \pm 142.49$ & $<0.001$ \\
Maximal amount of METS during exercise & $6.52 \pm 2.09$ & $8.13 \pm 2.06$ & $<0.001$ \\
Systolic blood pressure value at peak exercise $[\mathrm{mm} \mathrm{Hg}]$ & $160 \pm 16.64$ & $158.45 \pm 11.5$ & $\mathrm{NS}$ \\
Diastolic blood pressure value at peak exercise $[\mathrm{mm} \mathrm{Hg}]$ & $81.6 \pm 14.62$ & $81.36 \pm 10.82$ & $\mathrm{NS}$ \\
Maximal heart rate value at peak exercise & $134 \pm 13.86$ & $136.13 \pm 11.16$ & $\mathrm{NS}$ \\
Percentage of maximal predicted heart rate for given age & $82.4 \pm 8.74$ & $83.73 \pm 7.32$ & $\mathrm{NS}$ \\
\hline
\end{tabular}

*P for repeated measures Student's T-test; METS — metabolic equivalents

The average length of stress tests on the treadmill according to the modified Bruce protocol was $635.87 \mathrm{~s}$, with an average difficulty of $6.52 \mathrm{MET}$. The obtained load values were within normal limits.

After completion of a course of rehabilitation the study group showed a statistically significant mean decrease in body weight and BMI. Individual analysis showed a decrease in BMI in $70.91 \%$ (39 patients), and a small, insignificant increase in BMI in 29.09\% (16 patients). In all but one of the patients who reported weight gain, baseline BMI was within the normal range and stayed within normal range after rehabilitation.

While comparing the parameters obtained in the exercise test, a mean decrease from baseline in blood pressure, both SBP and DBP, was noted. Also, the majority of cases (53 patients; $96.36 \%$ ) showed improvement in stress test times and an increase in the achieved METs score (52 patients; $94.55 \%$ ). In the case of one patient the same METs score was noted, with the test slightly prolonged (35 s). Changes in all of the above-mentioned parameters are summarised in Table 1.

Comparison of the results obtained before the start of the rehabilitation programme with the results obtained after its completion showed a significant increase in perfusion in the stress study in the majority of subjects for both segments corresponding to the areas of individual coronary vessels and those corresponding to overall perfusion. For the rest studies, slightly lower values for perfusion were obtained for both segments corresponding to the areas of individual coronary vasculature and those corresponding to overall perfusion. However, those differences were significant only in the case of stress studies. In analysing the differences in perfusion of individual segments between the rest and stress tests carried out before the start of cardiac rehabilitation and at the end, a reduction was noted in the differences in perfusion in the segments corresponding to the areas of all three major coronary arteries. The clearest difference was found in the RCA area and to a lesser extent, the LAD area. Overall perfusion of the LV myocardium in the stress test was improved in 44 (80\%) patients, remained unchanged in eight (14.55\%) patients, and decreased in three $(5.45 \%)$ patients.

Changes in the differences in perfusion between SPECT MPI studies (resting baseline vs. resting test after completion of cardiac rehabilitation and stress study at baseline vs. stress study after completing cardiac rehabilitation) are summarised in Table 2.

\section{DISCUSSION}

One of the reasons that the basis for MA is incompletely understood is the inability to fully and reliably assess changes in microvascular function in the affected area of the myocardium through invasive testing or non-invasive measurements of coronary flow reserve, or finally through related changes in the reduction of contractility in the study area. When a large artery is affected, capturing such changes is much easier because the area of ischaemia corresponds to that of the arterial vasculature. In the case of MA, one must reckon with the possibility of only a partial perfusion defect (an affected small artery supplying blood, e.g. to only one part of the myocardium), which may not produce symptoms of transmural hypoperfusion. Additionally, even in a case where a large area of cardiac muscle is affected, the process does not necessarily apply to all vessels in the area. Changes can then be widely scattered, which may partially (or significantly) mask the symptoms of ischaemia. Ischaemia in a given area, however, may be sufficient to cause chest pain and ECG changes as well as the appearance of perfusion defects in a radionuclide test. Currently, it is believed that MA affects vessels with a diameter less than $500 \mu \mathrm{m}$ [8].

Having the capacity to conduct SPECT myocardial perfusion scintigraphy in the study group, we focused on selecting a group so that all patients, in whom changes in large arter- 
Table 2. Comparison of the results of scintigraphic assessment of left ventricular perfusion at baseline and after completion of cardiac rehabilitation

\begin{tabular}{|c|c|c|c|}
\hline Parameters & Baseline & After rehabilitation & $\mathbf{P}^{*}$ \\
\hline Summed stress score in left anterior descending artery region & $2.82 \pm 2.97$ & $1.67 \pm 2.19$ & $<0.01$ \\
\hline Summed stress score in circumflex coronary artery region & $0.54 \pm 1.02$ & $0.47 \pm 0.92$ & NS \\
\hline Summed stress score in right coronary artery region & $3.49 \pm 2.96$ & $2.27 \pm 2.17$ & $<0.01$ \\
\hline Total summed stress score for left ventricle perfusion & $6.95 \pm 3.16$ & $4.51 \pm 2.58$ & $<0.01$ \\
\hline Summed rest score in left anterior descending artery region & $1.53 \pm 2.0$ & $1.67 \pm 2.19$ & 0.241 \\
\hline Summed rest score in circumflex coronary artery region & $0.2 \pm 0.52$ & $0.31 \pm 0.60$ & 0.260 \\
\hline Summed rest score in right coronary artery region & $2.2 \pm 2.15$ & $2.36 \pm 2.40$ & 0.375 \\
\hline Total summed rest score for left ventricle perfusion & $3.93 \pm 2.71$ & $4.35 \pm 3.13$ & 0.102 \\
\hline $\begin{array}{l}\text { Summed difference score between stress and rest value } \\
\text { in left anterior descending artery region }\end{array}$ & $1.4 \pm 1.49$ & $0.47 \pm 1.05$ & $<0.01$ \\
\hline $\begin{array}{l}\text { Summed difference score between stress and rest value } \\
\text { in circumflex coronary artery region }\end{array}$ & $0.36 \pm 0.75$ & $0.16 \pm 0.50$ & $<0.01$ \\
\hline $\begin{array}{l}\text { Summed difference score between Stress and rest value } \\
\text { in right coronary artery region }\end{array}$ & $1.33 \pm 1.36$ & $0.25 \pm 0.58$ & $<0.01$ \\
\hline $\begin{array}{l}\text { Summed difference score between stress and rest value } \\
\text { for left ventricle perfusion }\end{array}$ & $3.09 \pm 1.58$ & $0.89 \pm 1.26$ & $<0.01$ \\
\hline
\end{tabular}

*P for repeated measures Student's T-test

ies had been previously excluded while perfusion disorders appeared in scintigraphy tests of myocardial perfusion in at least one segment, have a high probability of MA. To that end, after evaluating those patients and comparing the results from those at baseline, our study confirmed the extent of the positive impact of non-pharmacological intervention, which consisted of physical training in the form of rehabilitation, on the improvement of perfusion of the LV. Currently used methods of imaging in the diagnosis of $\mathrm{MA}$, based on reviews of CSX and MA include methods that show microvascular dysfunction, like positron emission tomography (PET), cardiac magnetic resonance imaging (CMRI), and SPECT [12]. Progress in the field of diagnostic imaging (CMRI, myocardial perfusion scintigraphy, PET using Rubidium-82, Oxygen-15, or Ammonia $\mathrm{N}-13$ ) over the past few years has, however, enabled the imaging of evidence of ischaemia in the majority of patients diagnosed with MA. But even using these imaging techniques, it is not always possible to unambiguously confirm perfusion disorders [13, 14].

Risk factors for MA and other forms of coronary heart disease may be identical. This raises the question of whether the modification of coronary risk factors (e.g. lifestyle, diet, exercise) would not have a positive impact on the treatment of MA. Data from the Women's Ischemia Syndrome Evaluation (WISE) study showed that, in patients with CSX and signs of microvascular coronary disorders, there is an annual risk of $2.5 \%$ of adverse episodes such as sudden cardiac death, myocardial infarction, stroke, and congestive heart failure $[15,16]$. In our study, a group of women was able to achieve a positive response, demonstrating improvement in overall physical performance and increased physical activity as well as weight loss and decreased BMI. It would seem that the effect was not only to improve the quality of life (less frequent and less severe pain in the chest), but also to improve blood pressure, itself also an independent risk factor for coronary heart disease.

Our study succeeded in demonstrating a significant correlation between improvement in myocardial perfusion in SPECT tests following cardiac rehabilitation and reduction in both the frequency and severity of pain in these patients. Some of the previously published studies [2-4] failed to establish an unequivocal relationship between the occurrence of chest pain and the presence of small ischaemic changes, which may seem absurd in the case of a disease which is counted among the forms of IHD, and therefore associated with the occurrence of typical angina. However, it should be noted that PET imaging using perfusion tracers like $\mathrm{O}^{15}, \mathrm{NH}_{3}-\mathrm{N}^{13}$ enabled measurement of coronary flow reserve with greater accuracy, thus enabling diagnose of MA [7]. While the vast majority of authors showed the relationship between severity of pain and deterioration of perfusion, or at least the lack of improvement of perfusion in areas affected by the disease $[15,17,18]$, there have also been studies denying the presence of myocardial perfusion defects during an episode of chest pain in patients with CSX [19]. In the latter study patients experienced increased sensitivity to pain, with no evidence of decreased perfusion and oxygenation in the changed areas, during administration of adenosine. However, it must be borne in mind that there are a number of phenomena in the human body that can activate pain receptors. An example of factors 
that might have a significant impact on the occurrence of microvascular dysfunction and related pain symptoms is the activation of inflammatory processes [20, 21].

At rest, patients with MA usually demonstrate normal or slightly reduced blood flow in peripheral vessels. However, it changes during physical exercise, during which the increase in blood flow is about $20 \%$ lower in the case of MA patients as compared to healthy individuals. This limit is related to an impaired capacity for vascular relaxation or overly potent vasoconstriction during exercise. The reason for this is the very low level of nitric oxide released from the endothelial cells of small blood vessels that supply the metabolically active muscle groups, along with increased release of vasomotor factors (mainly endothelin, norepinephrine, renin, angiotensin II, and vasopressin). In spite of not being able to reliably assess endothelial function, when bearing in mind the findings of other authors $[4,22]$ it seems that the results obtained in our study support the thesis that regular exercise training improves endothelial function, reduces peripheral vascular resistance, and consequently improves perfusion and skeletal muscle blood flow. This results in improvement in perfusion and enhancement of the diffusion of oxygen in muscle, which is demonstrated by an increase in muscle strength and capacity to prolong exercise. Physical training also has a positive effect on reducing overweight and obesity [23, 24], which we also had to deal with in our group. Cardiac rehabilitation of women with MA brings about a measurable improvement in the perfusion of $L V$ in radionuclide tests. Such improvement is essential, resulting not only in a clinical improvement observed in the group of patients undergoing rehabilitation, but also in an improved prognosis. As we know from epidemiological studies, which form the basis for standards of practice in ESC IHD, in patients with improved myocardial perfusion and clinical improvement the risk of an acute coronary event and sudden cardiac death is reduced [7].

Nowadays it is confirmed that regular exercise training conducted within the framework of cardiac rehabilitation can be an effective means of preventing or reversing the structural, morphological, and resulting functional changes in the cardiac muscle. We can assume that physical training (including for patients with MA) does not cause further damage to the heart and probably contributes to the improvement of morphological, functional, and metabolic parameters. However, further studies are needed to answer the question: what is the impact of physical training on patients with MA in the LV and on the parameters defining its function?

\section{Limitations of the study}

There is a limitation we are aware of in the current study. Usage of the stress test in the MPI study, which should be replaced by adenosine or dipyridamole stress testing. However, due to the study design, with the involvement of cardiac rehabilitation we thought it would be more convenient if we actually use treadmill stress testing to better reflect the benefits of rehabilitations.

\section{CONCLUSIONS}

Cardiac rehabilitation of women with MA brings about a measurable improvement in perfusion of the LV in radionuclide tests.

\section{Conflict of interest: none declared}

\section{References}

1. Kemp HG. Left ventricular function in patients with the anginal syndrome and normal coronary arteriograms. Am J Cardiol, 1973; 32: 375-376.

2. Cannon RO, Epstein SE. "Microvascular angina" as a cause of chest pain with angiographically normal coronary arteries. Am J Cardiol, 1988; 61: 1338-1343.

3. Pupita G, Kaski JC, Galassi AR et al. Long-term variability of angina pectoris and electrocardiographic signs of ischemia in syndrome X. Am J Cardiol, 1989; 64: 139-143.

4. Singh M, Singh S, Arora R, Khosla S. Cardiac syndrome X: current concepts. Int J Cardiol, 2010; 142: 113-119. doi: 10.1016/j. ijcard.2009.11.021.

5. Kaski JC, Elliot PM. Angina pectoris and normal coronary arteriograms: clinical presentation and hemodynamic characteristics. Am J Cardiol, 1995; 76: 35-42.

6. Herrmann J, Kaski JC, Lerman A. Coronary microvascular dysfunction in the clinical setting: from mystery to reality. Eur Heart J, 2012; 33: 2771-2782. doi: 10.1093/eurheartj/ehs246.

7. 2013 ESC guidelines on the management of stable coronary artery disease. The Task Force on the management of stable coronary artery disease of the European Society of Cardiology. Eur Heart J, 2013; 34: 2949-3003. doi: 10.1093/eurheartj/eht296.

8. Samim A, Nugent L, Mehta PK et al. Treatment of angina and microvascular coronary dysfunction. Curr Treat Options Cardiovasc Med, 2010; 12: 355-364. doi: 10.1007/s11936-010-0083-8.

9. Hesse B, Tagil K, Cuocolo A et al. EANM/ESC procedural guidelines for myocardial perfusion imaging in nuclear cardiology. Eur J Nucl Med Mol Imag, 2005; 32: 855-897.

10. Hesse B, Lindhardt TB, Acampa W et al. European Association of Nuclear Medicine/European Society of Cardiology guidelines for radionuclide imaging of cardiac function. Eur J Nucl Med Mol Imag, 2008; 35: 851-885. doi: 10.1007/s00259-007-0694-9.

11. Wenger NK. Cardiac rehabilitation: United States. In: Perk J, Mathes P, Gohlke $\mathrm{H}$ et al. eds. Cardiovascular prevention and rehabilitation. Springer 2007: 34-36.

12. Arthur HM, Campbell P, Harvey PJ et al. Women, cardiac syndrome X, and microvascular heart disease. Can J Cardiol, 2012; 28 (2 suppl.): S42-S49. doi: 10.1016/j.cjca.2011.09.006.

13. Panting JR, Gatehouse PD, Yang GZ et al. Abnormal subendocardial perfusion in cardiac syndrome $\mathrm{X}$ detected by cardiovascular magnetic resonance imaging. N Engl J Med, 2002; 346: 1948-1953.

14. Buchthal SD, den Hollander JA, Merz CN et al. Abnormal myocardial phosphorus-31 nuclear magnetic resonance spectroscopy in women with chest pain but normal coronary angiograms. N Engl J Med, 2000; 342: 829-835.

15. Reis SE, Holubkov R, Conrad Smith AJ et al. WISE Investigators. Coronary microvascular dysfunction is highly prevalent in women with chest pain in the absence of coronary artery disease: results from the NHLBI WISE study. Am Heart J, 2001; B141: 735-741.

16. Johnson BD, Shaw LJ, Buchthal SD et al. Prognosis in women with myocardial ischemia in the absence of obstructive coronary disease. Results from the National Institutes of Health - National 
Heart, Lung, and Blood Institute — sponsored Women's Ischemia Syndrome Evaluation (WISE). Circulation, 2004; 109: 2993-2999.

17. Lanza GA, Buffon A, Sestito A et al. Relation between stress-induced myocardial perfusion defects on cardiovascular magnetic resonance and coronary microvascular dysfunction in patients with cardiac syndrome X. J Am Coll Cardiol, 2008; 51: 466-472. doi: 10.1016/j.jacc.2007.08.060.

18. Camici PG, Rimoldi OE. The clinical value of myocardial blood flow measurement. J Nucl Med, 2009; 50: 1076-1087. doi: 10.2967/jnumed.108.054478.

19. Karamitsos TD, Arnold JR, Pegg TJ et al. Patients with syndrome X have normal transmural myocardial perfusion and oxygenation: a 3-T cardiovascular magnetic resonance imaging study. Circ Cardiovasc Imaging, 2012; 5: 194-200. doi: 10.1161/CIRCIMAGING.111.969667.
20. Arroyo-Espliguero R, Kaski JC. Microvascular dysfunction in cardiac syndrome X: the role of inflammation. CMAJ, 2006; 174: 1833-1834.

21. Desideri G, Gaspardone A, Gentile M et al. Endothelial activation in patients with cardiac syndrome X. Circulation, 2000; 102: 2359.

22. Wu EB. Microvascular dysfunction in patients with cardiac syndrome X. Heart, 2009; 95: 521-521. doi: 10.1136/hrt. 2008.160689.

23. Adams JL, Nuss TMS, Banks C et al. Risk factor outcome comparison between exercise-based cardiac rehabilitation, traditional care, and an educational workshop. J Cont Education in Nursing, 2007; 38: 83-88.

24. Fletcher GF. Cardiac rehabilitation: something old-something new-more to do. J Cardiopulmonary Reh Prev, 2007; 27: 21-23.

Cite this article as: Szot W, Zając J, Kubinyi A, Kostkiewicz M. The effects of cardiac rehabilitation on overall physical capacity and myocardial perfusion in women with microvascular angina. Kardiol Pol, 2016; 74: 431-438. 10.5603/KP.a2015.0198. 


\title{
Wpływ rehabilitacji kardiologicznej na wydolność fizyczną i perfuzję mięśnia sercowego u kobiet $z$ chorobą drobnych naczyń wieńcowych
}

\author{
Wojciech Szot ${ }^{1,2}$, Joanna Zając ${ }^{1}$, Aleksandra Kubinyi ${ }^{3}$, Magdalena Kostkiewicz ${ }^{2,4}$ \\ 'Zakład Higieny i Dietetyki, Uniwersytet Jagielloński, Collegium Medicum, Kraków \\ ZZakład Medycyny Nuklearnej, Szpital im. Jana Pawła II, Kraków \\ ${ }^{3}$ Centrum Rehabilitacyjne Belluga-Med, Kraków \\ ${ }^{4}$ Klinika Chorób Serca i Naczyń, Uniwersytet Jagielloński, Collegium Medicum, Kraków
}

\section{Streszczenie}

Wstęp: Kardiologiczny zespół X (CSX) wiąże się ze zmianami w mikrokrążeniu serca przy braku istotnych hemodynamicznie zmian w obrębie głównych naczyń wieńcowych. W obecnie obowiązujących, opublikowanych w 2013 r. roku kryteriach Europejskiego Towarzystwa Kardiologicznego dotyczących postępowania w stabilnej chorobie wieńcowej (CAD), jedynie wspomina się o CSX, uznając za bezpośrednią przyczynę tego zespołu chorobę drobnych naczyń (MA). Główną cechą MA, na której oparto diagnostykę tego schorzenia, powinno być lokalne niedokrwienie mięśnia sercowego, przy czym należy jednak zwrócić uwagę, że w kilku doniesieniach naukowych nie potwierdzono obecności patologicznych zmian w perfuzji mięśnia sercowego.

Cel: Celem niniejszej pracy było zobrazowanie zaburzeń perfuzji lewej komory w grupie kobiet ze zdiagnozowaną MA za pomocą scyntygrafii perfuzyjnej mięśnia sercowego metodą tomografii emisyjnej pojedynczych fotonów (SPECT) oraz obserwacja zmian w perfuzji i wydolności fizycznej po 3-miesięcznej rehabilitacji kardiologicznej.

Metody: Spośród 528 kobiet poddanych badaniom przesiewowym w kierunku CAD, po rozpoznaniu MA, zgodę na dalszy udział w badaniu i 3-miesięczną rehabilitację kardiologiczną wyraziło 55 pacjentek. Przeprowadzono ocenę perfuzji mięśnia sercowego w badaniu spoczynkowym i wysiłkowym, wyjściowo oraz po zakończeniu rehabilitacji kardiologicznej, jak również ocenę wydolności w trakcie testów wysiłkowych na bieżni ruchomej.

Wyniki: Porównanie danych wyjściowych oraz po 3 miesiącach rehabilitacji kardiologicznej wykazało poprawę zarówno w zakresie parametrów testu wysiłkowego (czas trwaniu próby wysiłkowej, osiągnięta liczba równoważnika metabolicznego, parametry ciśnienia tętniczego krwi w czasie trwania próby), jak i parametrów perfuzji lewej komory w badaniu SPECT (podczas spoczynku i wysiłku, perfuzja całkowita i regionalna lewej komory).

Wnioski: Rehabilitacja kariologiczna stanowi wartościowe narzędzie w leczeniu pacjentów z MA.

Słowa kluczowe: rehabilitacja kardiologiczna, obrazowanie perfuzji mięśnia sercowego, choroba drobnych naczyń

Kardiol Pol 2016; 74, 5: 431-438 